\title{
An Analysis on the Persuasive Elements in the Malaysian Public Universities' Digital Promotional Materials
}

\author{
Nor Atifah Mohamad, Normah Abdullah, Ameiruel Azwan Ab Aziz
}

To Link this Article: http://dx.doi.org/10.6007/IJARBSS/v11-i10/11462

DOI:10.6007/IJARBSS/v11-i10/11462

Received: 07 August 2021, Revised: 30 August 2021, Accepted: 17 September 2021

Published Online: 13 October 2021

In-Text Citation: (Mohamad et al., 2021)

To Cite this Article: Mohamad, N. A., Abdullah, N., \& Aziz, A. A. A. (2021). An Analysis on the Persuasive Elements in the Malaysian Public Universities' Digital Promotional Materials. International Journal of Academic Research in Business and Social Sciences, 11(10), 1024 - 1037.

\section{Copyright: @ 2021 The Author(s)}

Published by Human Resource Management Academic Research Society (www.hrmars.com)

This article is published under the Creative Commons Attribution (CC BY 4.0) license. Anyone may reproduce, distribute, translate and create derivative works of this article (for both commercial and non-commercial purposes), subject to full attribution to the original publication and authors. The full terms of this license may be seen at: http://creativecommons.org/licences/by/4.0/legalcode

Vol. 11, No. 10, 2021, Pg. 1024 - 1037

Full Terms \& Conditions of access and use can be found at http://hrmars.com/index.php/pages/detail/publication-ethics 


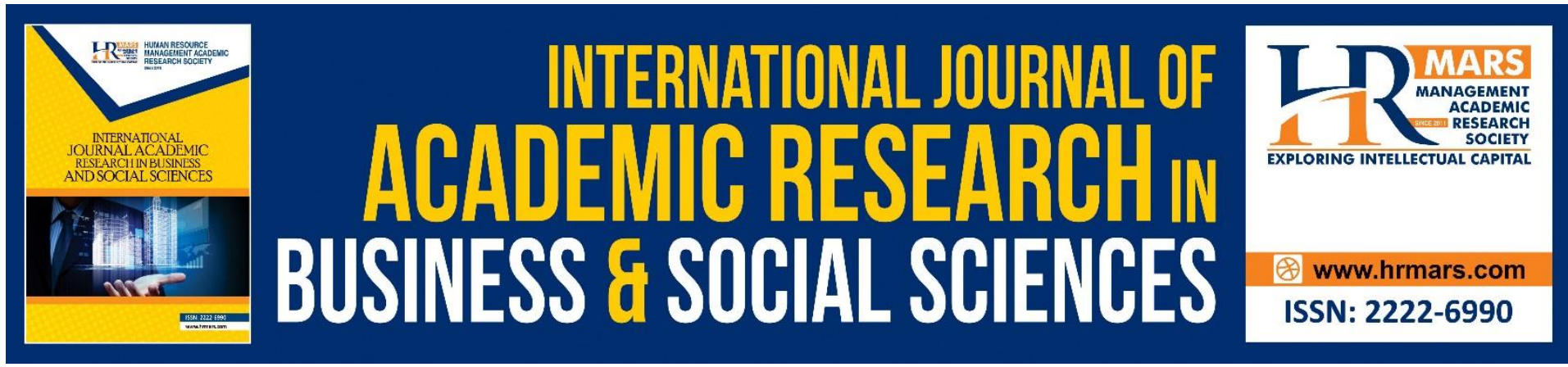

\title{
An Analysis on the Persuasive Elements in the Malaysian Public Universities' Digital Promotional Materials
}

\author{
Nor Atifah Mohamad, Normah Abdullah, Ameiruel Azwan Ab \\ Aziz \\ Akademi Pengajian Bahasa, Universiti Teknologi MARA Cawangan Melaka \\ Email: atifah740@uitm.edu.my,norma034@uitm.edu.my, ameirul@uitm.edu.my
}

\begin{abstract}
University digital promotional materials act as a communication tool between the university and prospective students. The materials are crucial to entice prospective students and employ the persuasion elements to attract much-needed attention. Nevertheless, there is a breach in the existing literature in which little research has focused on persuasive discourse in Malaysian public universities' promotional materials. The proposed study intends to examine further the different extent of the combination of textual and visual elements used in the digital promotional materials to achieve its persuasive function in the Malaysian public universities' promotional materials. This study will focus on all twenty Malaysian public universities' promotional materials embedded in their institutional website. Metadiscourse analysis will be used to analyse the persuasive elements. All data will be analysed and categorised, and emerging meta-discursive themes will be presented to answer research questions. With great hope, the results of this study can provide further recommendations for interventions from universities' websites and content developers to improve the linguistics presentations to attract larger student enrolment.
\end{abstract}

Keywords: Digital Promotional Materials, Institutional Website, Persuasive Elements

\section{Introduction}

The prestige of pursuing education to the tertiary level has led the education institutions to market their service to the prospective students massively. However, with the vast number of higher education institutions available offering a similar service, the marketisation of higher education institutions through their promotional materials is always vivid. Correspondingly, the decision-making process to continue education at the tertiary level is always daunting to the prospective students, either the school leavers or industry professionals who would like to boost their academic credentials. Studies have shown that the decision-making process is heavily influenced by the promotional materials (Bai, Yao, \& Dou, 2015; Falk, 1984; Huang \& Benyoucef, 2015; Mathews \& Arway, 1987; Samad, Salim, \& Akib, 2018). The decision-making process does affect not only cognitive ability but also visceral appraisals (Argyriou \& Melewar, 2011). Schwarz and Bohner (2001) also highlight that estimating people's preferences towards any promotional media stem from the attitude 
theory that suggests rational appraisals or cognitive appraisal and thoughts and feelings or the affective appraisal play a part in the decision-making process. Thus, understanding the nature of the promotional materials based on these appraisals can provide guidance in developing effective promotional materials.

Effective promotional materials understandably consist of a framing effect. The framing effect is how the information or outcome is presented that influences the person's decision-making process (Fagley \& Miller, 1997; Fan, 2017; Miu \& Crisan, 2011). Ostensibly during this process, the person is susceptible to the perceived gains or losses associated with the information. Hence, the promotional materials must be presented with good gains or losses to ensure their readers have a favourable decision. Concerning tertiary education, the prospective students' primary gain of continuing education includes equipping themselves with the latest skills and knowledge that can spontaneously lead to a better job prospect (Aslanian, 2007). However, the losses in the context of continuing education include the financial requirement and the individual academic identity challenges that entail self-esteem and the sense of belonging in the academic world (Lee \& Kramer, 2013; Roksa, Feldon, \& Maher, 2018; Terenzini et al., 1994).

Along with the recent changes in study fees and their impact on the prospective students' personal and professional lives (Kok, 2014; Teichler \& Hanft, 2009), these factors continuously assault their decision to further their studies. With these perceived losses, the percentage of Malaysian education enrollment is affected. As expected, the number of local student enrolment in the Malaysian Public Higher Education Institutes decreases from 95.53\% in 2015 to $94.29 \%$ in 2020, and this downward trend needs to be addressed.

Student enrolment in higher education institutes is imperative for Malaysia to join the rank of an advanced nation by 2020 . The aspiration to become an advanced nation was introduced during the $6^{\text {th }}$ Malaysia plan in 1991. Hitherto, this aspiration is yet to be realised due to the sluggish economic performance. Unfortunately, Malaysia has also fallen behind its regional counterparts, and the government has outlined several measures to help progress the nation. New Economic Model (NEM) was launched in 2010 to communicate the actions taken by the government to transform the middle-class income into a high-income society. To make this a reality, NEM has outlined the strategies needed, including developing a quality workforce. Hence, Malaysian tertiary education institutions are tasked to develop the competent and highly skilled citizen needed to meet the workforce requirement and increase the country's productivity (Kenayathulla, Ahmad, \& Idris, 2019).

Nevertheless, in this digital age, these tertiary education institutions are not shielded by various shifts brought upon by the global advancement of information and communication technology and the country's economic obligation (Ahmed, 2016). Globalisation, massification, and computer-based learning processes in the tertiary education institutes require these institutions to change to sustain in this sector. Analogously, the sudden outbreak of COVID-19 hampers the tertiary education institutions to function normally, also pose a challenge for the institutions. Regardless, to encapsulate these needs and changes, marketisation of higher education is highly needed to ensure the students' enrolment will not be an issue and a quality workforce will be produced.

Higher education institutions' marketisation is needed to advertise the service offered by these tertiary institutions to prospective students. This process makes use of various marketing methods to reach the intended audience. Promotional materials such as brochures, prospectuses, and websites are the current marketing trend the tertiary institutions employ. Authors such as Brown and Sen (2010); Zhang (2017) attest that lexical, 
grammatical and visual choices are common in these promotional materials and these affect the prospective students' decision in enrolling in the institution. Fairclough contends that these promotional materials are "new hybrid partly promotional genres" (1993, p. 139) and have been blatantly set out to be the primary medium to attract the attention of the prospective students to enrol in their university (Askehave, 2007).

This paper discusses the importance of persuasion in digital promotional materials by the higher education institutions in Malaysia. It presents the need to influence the prospective students to continue their tertiary education in the Malaysian Public Higher Learning Institutions. This study will begin with the function of university students as the human capital in achieving the notion of a developed nation. This is followed by the persuasive discourse employed by the institutions in the recent decade. In addition, this paper will explain the proposed persuasive method to develop promotional materials for prospective students.

\section{Malaysia's Aspiration}

It is known that Malaysia is aspiring to become a high-income country but has yet to be fulfilled. This aspiration recognises the need for high-quality human capital to ensure a more significant economic capacity, which is needed to propel the nation into a developed country status (The World Bank, 2021). Hitherto, Malaysia has devised and executed a consecutive five-year economic plan, namely the Malaysia Plan (MP), since 1956 to guide and boost the nation's growth to become a developed country. On a macro level, Malaysia also participated in the 2030 Agenda for Sustainable Development (2030 Agenda) set by the United Nations (UN) in 2015. 2030 Agenda consists of Sustainable Development Goals (SDGs) that aim to create a well-founded, more robust, and holistic development for the betterment of the people and the planet. Among the goals are to eradicate poverty and hunger, create decent work and economic growth and provide quality education. On a micro level, the aims of transitioning to a high-income country are to create a stable and robust local economy, produce high-skilled and high-paying jobs, reformation of the government sector, and reduce inequalities between the societal and state levels and empower the nation's shared revenue (World Bank, 2021). Acknowledging the importance of highly trained professionals for local and international agenda, Malaysia has long integrated the SDGs in the Eleventh Malaysia Plan (11MP), 2016-2020, and currently into the Twelfth Malaysia Plan (12MP) 2021-2025 (Economic Planning Unit, 2021).

In conjunction with this, Malaysia is shifting from a production-based economy to knowledge-based resources. The responsibility to produce the necessary highly skilled workforce integral in the present climate is entrusted to the Malaysian tertiary education institutions. Recognising the indispensable role of higher education institutions for the nation's workforce, the Malaysian Education Ministry promotes the concept of lifelong learning to entice the secondary-school leavers and adult learners to participate in education beyond their formal secondary-school level (Guan, 2011). Concerning this, public universities are the leading agents (Ithnin, 2018) to offer various academic programmes to help learners acquire the academic qualification needed to strive in the current market. However, with a high number of private universities, university colleges, international branch campuses, colleges and accredited skills training centres, Malaysian public universities must compete with the other institutions for students' admission. Offering similar services with various institutions warrants the Malaysian public universities to employ various marketing tactics to 
increase their admission through billboard advertisement, education fair, and internet promotion on their institutional website.

However, during the COVID-19 pandemic, social distancing, restrictions on social gatherings, travel restrictions (Lim et al., 2021), and new norms were implemented as a measure to break the chain of COVID-19. The effect of the pandemic is felt throughout all sectors, and higher education is not spared. The new normal requires the operation of the higher learning institutes to be mostly done virtually from teaching and learning, research to students' admission. As per traditional student fair holds every year to promote students' admission, Malaysian universities need to optimise their digital promotional materials as their primary medium for attracting prospective students. Scholars like Burrell (2013); Baker (2015); Lampley and Owens (2015) assert that prospective students' first contact with the university is the university website and, more specifically, the student's admission webpage. The students' admission webpage is frequented as it consists of the information needed for prospective students to enrol into the university. Hence, the university must transmit information to the prospective students and persuade their opinion towards the institution.

\section{Persuasion}

Persuasion is ubiquitous and pervades every aspect of human interaction. Either subtle like mass media or direct like an advertisement, human is inherently incapable of avoiding persuasion as it persists in various settings such as formal and informal settings, and it can be relayed through spoken, textual, or visual medium. Simons, Morreale and Gronbeck (2001) define persuasion as a form of social communication deliberately to influence an individual's opinion or assessments and behaviour concerning others. It is important to note that persuasion is done deliberately and acts as the onset of attitudinal change (Guerini, Stock, \& Zancanaro, 2007; O'Keefe, 1990). Scholars like O'Keefe (2002) and Virtanen and Halmari (2005) stress the importance of language in the persuasive process, noting that the process affects the individual's opinion on a particular matter and can also strengthen their own belief and behaviours. Dillard (2010) extends the definition of persuasion as "the use of symbols (sometimes accompanied by images) by one social actor for the purpose of changing or maintaining another social actor's opinion or behaviour" (p. 203). Hence, this insinuates that Malaysian public universities are utilising institutional discourse in their digital promotional materials. Institutional discourse is the communication between people who may not know each other but communicate in accordance with the norms and rules of the institution at play (Sarangi \& Roberts, 1999). Bhatia (2005) declares that the current institutional discourse is also embedded with promotional discourse. Various research has been conducted on the promotional discourse in online advertisement (Popova, 2018), speeches (Han, 2014), religious texts (Adam, 2017), mission statements (Morrish \& Sauntson, 2013). On another note, images also affect persuasion (Seo, 2020). Authors such as Peracchio and Meyers-Levy (2005) and Miniard, Bhatla, Lord, Dickson, and Unnava (1991) the visual properties in the printed message and readers' involvement in the texts influence their opinion on the overall text. Hence, as reviewed so far, all of these studies have shown evidence of promotional discourse. However, with the current marketisation of higher institutions, university promotional materials consisting of textual and visual persuasion are still not given their due attention. 


\section{Elaboration Likelihood Model}

The central concept of persuasion is the Elaboration Likelihood Model (ELM) that allows the researcher to organise, categorise and understand the rudimentary element of persuasion (Petty, Kasmer, Haugtvedt, \& Cacioppo, 1987). The model posited by Petty and Cacioppo in 1981 describes the thinking process that occurs when an individual tries to persuade another individual and induce behaviour change. The model works on the premise that an individual can change their opinion, position, or behaviour if one carefully and thoughtfully considers the opinion one subscribes. Correspondently, any element in the persuasion process can either positively or negatively affect the behaviour change in an individual (Tormala \& Petty, 2004). This model works on the assumption that an individual can change their notion, position, or behaviour if they give careful consideration and thought to their advocates. This thinking process falls on the elaboration continuum whereby if the persuasive message is not given any thought to the issue, it is on the low elaboration spectrum (low elaboration likelihood). The highly contemplated message falls on the high elaboration spectrum (high elaboration likelihood). Wagner and Petty (2011) affirm that the extent of thinking or elaboration about an idea may be high or low along the elaboration continuum. The researchers also assert that the elaboration continuum determines whether the idea persuades an individual or not.

There are two conditions for an individual to immerse in persuasion's thinking or elaboration process: motivation and ability. These motivation and ability will affect the thinking process and later determine the place for the individual along the elaboration continuum. Motivation is defined as the urge to spend the high cognitive effort to process a message (Petty, Wheeler, \& Tormala, 2003). Ability is the condition needed by the individual to understand the message, which includes the individual's capacity and opportunity to think. However, the ability is commonly affected by various factors such as intelligence, time to engage with the message, perceived knowledge, distraction in the communication process, and message repetition (Rucker \& Petty, 2006). In sum, having different motivation levels and ability in processing persuasive communication have different effects on the individual.

The model describes the dual routes in persuasion: the central route processing and the peripheral route processing. Central route or central processing uses argument quality to stimulate the individual's involvement towards the information presented. Argument quality refers to the receiver's analysis on the merit or the quality of the information, numbers, or opinion presented in the information before making any decision (Petty \& Cacioppo, 1986). Characteristically, an individual with high motivation will follow this central route of processing and subsequently process the information presented carefully and thoroughly. This thoughtful process is the wanted effect as it induces attitude change in an individual, long-lasting, and more impervious to change (Haugtvedt \& Petty, 1989). The second route is the peripheral route or peripheral processing that needs only some degree of cognitive effort and relies on cues such as the attractiveness or mood of the receiver before making an opinion. This peripheral processing is void of a textual or informational aspect of the persuasive message and prefers the use of senses and other mechanisms such as simple cues or mental short-cut in processing the information in the message (Chaiken, 1980; Petty \& Cacioppo, 1981; Stiff, 1993). Unlike the central route processing, the decision-derived peripheral route is vulnerable to counter-argument, temperamental, and loses its effect after a certain period (Rucker \& Petty, 2006; Wagner \& Petty, 2011).

The discussion so far hinted at the use of the two basic routes of persuasion, which differ in the elaboration likelihood continuum. However, in the context of persuasion in 
Malaysian public universities' digital promotional materials, the materials attract a specific group of audience who have the ability and motivation or high elaboration likelihood to gain the university's entrance. Nonetheless, past research has shown that no main route effectively persuades the audience to believe in the content presented. Tseng and Wang (2016) agreed that individuals with high elaboration-likelihood pay close attention to the information presented to them compared to individuals with low elaboration likelihood who used peripheral route processing. In the study conducted by Cyr et al (2015), peripheral route processing through the use of image appeal and design highly affected the high elaboration likelihood individual rather than the information. In another study conducted by Cyr, Head, Lim, and Stibe (2018), the research also found that the peripheral route significantly affects an individual's persuasion. Hence, it is essential to note that both routes complement one another. Guadagno and Cialdini (2009) also assert that an individual utilises the dual routes under different circumstances. Therefore, it is crucial to examine the textual and visual features presented in the Malaysian public universities' digital promotional materials to understand better the persuasive elements used in the materials.

\section{Textual and Visual Metadiscourse}

The aim of this study is to explore the persuasive elements in the Malaysian public universities' promotional materials using Hyland's Interpersonal Framework of Metadiscourse. Hyland (2005) notes that people consciously select the language used in their daily communication. This view argues that the author does write a text to transmit information or describe the world to the reader only and ensure that the information presented is comprehensible and suitable for the reader. Essentially, the author needs to retain the reader's interest and encourage them to follow through (Amiryousefi, 2010). Therefore, the author must foresee the reader's anticipation, necessities, and conditions to encourage the reader to engage with the texts, and this continuous engagement is continuously deemed a social-communicative process (Hyland \& Tse, 2004; Hyland, 2004; Hyland, 2005). This interpersonal relationship between the author and the readers is coherent with the concept of metadiscourse. Metadiscourse is "The cover term for the self-reflective expressions used to negotiate interactional meanings in a text, assisting the writer (or speaker) to express a viewpoint and engage with readers as members of a particular community" (Hyland, 2005: p. 37). Hence based on the definitions, Hyland proposed a model of metadiscourse, namely the Interpersonal Framework of Metadiscourse, which is shown in Table 1. The model proposed distinguishes interactive and interactional resources. Interactive resources are how the writer organises the text and mirrors the writer's consideration of what needs to be made explicit and what needs to be implicit in the text. Interactional resources focus on the readers and display their personalities towards the data and the readers themselves. 
Table 1: Hyland's (2005) Interpersonal Framework of Metadiscourse

\begin{tabular}{|c|c|c|}
\hline \multicolumn{2}{|c|}{ Interactive: help to guide the reader through the text } & Examples \\
\hline Transitions & Express relations between main clauses & $\begin{array}{l}\text { in addition; but; } \\
\text { thus }\end{array}$ \\
\hline Frame markers & Refer to discourse acts, sequences, or stages & finally; to conclude \\
\hline $\begin{array}{l}\text { Endophoric } \\
\text { markers }\end{array}$ & $\begin{array}{l}\text { Refer to the information in other parts of the } \\
\text { text }\end{array}$ & $\begin{array}{l}\text { noted above; see } \\
\text { table } X\end{array}$ \\
\hline Evidentials & Refer to information from other texts & $\begin{array}{l}\text { according to } \mathrm{X} ; \mathrm{Y} \\
\text { argued }\end{array}$ \\
\hline Code glosses & Elaborate propositional meanings & $\begin{array}{l}\text { that is; in other } \\
\text { words }\end{array}$ \\
\hline \multicolumn{2}{|c|}{ Interactional: involve the reader in the text } & Examples \\
\hline Hedges & Withhold commitment and c & may; perhaps \\
\hline Boosters & Emphasise certainty or close dialogue & $\begin{array}{l}\text { certainly; it is clear } \\
\text { that }\end{array}$ \\
\hline Attitude markers & Express writer's attitude to the proposition & $\begin{array}{l}\text { surprisingly; } \\
\text { unfortunately }\end{array}$ \\
\hline Self-mentions & Refer explicitly to the author & I; we; my; our \\
\hline $\begin{array}{l}\text { Engagement } \\
\text { markers }\end{array}$ & Build explicitly relationship with reader & $\begin{array}{l}\text { please note that; } \\
\text { consider }\end{array}$ \\
\hline
\end{tabular}

Metadiscourse is derived from the notion that the author uses language to transmit information and the author's beliefs and attitudes. Vande Kopple (2002) reiterates that metadiscourse allows readers to "connect, organise, interpret, evaluate, and develop attitudes towards materials" (p. 93). Hyland (2005) also asserts that "Metadiscourse embodies the idea that communication is more than just exchange of information, goods or services, but also involves the personalities, attitudes and assumptions of those who are communicating" (p. 3). Consequently, metadiscourse is regarded as the author's effort in achieving persuasive appeals, namely ethos (appeal to credibility and character), logos (making the rational appeal), and pathos (appeal to emotion). Hyland (2005) affirms that ethos can be realised through hedges and boosters, logis can be achieved using interactive metadiscourse and pathos can be obtained with interactional metadiscourse.

In order to analyse the visuals that appeared in the Malaysian Public HLIs' promotional materials, De Groot et al (2015) Model of Visual Metadiscourse and Photographic Realisation will be used. Deriving from Kress and Van Leeuwen's (2006) multimodal work that has developed a systematic manner of analysing images, this visual metadiscourse and photographic realisation incorporated the model with the Hyland and Tse (2004) work. However, there is a void in De Groot et al.'s model as the model does not include frame markers and hedges as these elements were not visible in their data set, but this study will address these elements if the data occur. Hence, using this model will help align the textual and visual elements in the Malaysian Public HLIs' promotional materials from the metadiscourse perspective. 
Table 2: Model of Visual Metadiscourse and Photographic Realization (De Groot et al., 2015) Compositional (Interactive Resources) that help readers to interpret photographic content

\begin{tabular}{|c|c|c|c|}
\hline Category & Function in visuals & $\begin{array}{c}\text { Visual } \\
\text { components }\end{array}$ & Example \\
\hline Transitions & $\begin{array}{l}\text { Express semantic relationship } \\
\text { between sections or fragments } \\
\text { in the text in order to establish } \\
\text { a central theme throughout the } \\
\text { report (e.g., by including photos } \\
\text { that are semantically related) }\end{array}$ & $\begin{array}{l}\text { Objects } \\
\text { Activities } \\
\text { Clothing } \\
\text { Scene }\end{array}$ & $\begin{array}{l}\text { Consistent portraits } \\
\text { of men and women }\end{array}$ \\
\hline Evidentials & $\begin{array}{l}\text { Refer to the additional source(s) } \\
\text { affirming company information } \\
\text { in order to prove the company's } \\
\text { high capacity or professionalism } \\
\text { (e.g., by portraying people or } \\
\text { organisations that have } \\
\text { applauded the company) }\end{array}$ & $\begin{array}{l}\text { Objects } \\
\text { Activities } \\
\text { Clothing } \\
\text { Scene }\end{array}$ & $\begin{array}{l}\text { Image of award } \\
\text { adjoining a text }\end{array}$ \\
\hline Code glosses & $\begin{array}{l}\text { - Exemplify or specify ideational } \\
\text { materials (i.e., company } \\
\text { information) } \\
\text { - Illustrate the factual internal } \\
\text { or external identity of the } \\
\text { company represented in the } \\
\text { text } \\
\text { - Illustrate the instrumental } \\
\text { value of the comp } \\
\text { - any's products or services } \\
\text { - Illustrate the market and } \\
\text { marketing activities of the } \\
\text { company, product, or service } \\
\text { - Improve the readability of the } \\
\text { text by visualising abstract } \\
\text { written information }\end{array}$ & $\begin{array}{l}\text { Objects } \\
\text { Activities } \\
\text { Clothing } \\
\text { Scene }\end{array}$ & $\begin{array}{l}\text { Image related to } \\
\text { the company }\end{array}$ \\
\hline
\end{tabular}

\begin{tabular}{l}
$\begin{array}{l}\text { Interpersonal (Interactional Resources) that help readers to interpret photographic } \\
\text { content }\end{array}$ \\
\hline \multicolumn{1}{c}{ Category }
\end{tabular}




\begin{tabular}{|c|c|c|c|}
\hline $\begin{array}{l}\text { Attitude } \\
\text { markers }\end{array}$ & $\begin{array}{l}\text { - Express sender's attitude } \\
\text { toward (company-related) } \\
\text { proposition } \\
\text { - Illustrate the associative } \\
\text { internal or external identity of } \\
\text { the company represented in } \\
\text { the text }\end{array}$ & $\begin{array}{l}\text { Objects } \\
\text { Facial } \\
\text { expressions } \\
\text { and poses } \\
\text { Activities } \\
\text { Clothing } \\
\text { Scene }\end{array}$ & $\begin{array}{l}\text { Portrait of smiling, } \\
\text { happy people }\end{array}$ \\
\hline $\begin{array}{l}\text { Engagement } \\
\text { markers }\end{array}$ & $\begin{array}{l}\text { Build a relationship with readers } \\
\text { in order to appeal to their } \\
\text { emotions or attitudes }\end{array}$ & $\begin{array}{l}\text { Objects } \\
\text { Facial } \\
\text { expressions } \\
\text { and poses } \\
\text { Camera view }\end{array}$ & $\begin{array}{l}\text { Close-up intimate } \\
\text { image }\end{array}$ \\
\hline Self-mentions & $\begin{array}{l}\text { Refer to the author(s) of the text } \\
\text { in order to provide the company } \\
\text { with personal face }\end{array}$ & $\begin{array}{l}\text { Objects } \\
\text { Pose } \\
\text { Clothing } \\
\text { Scene }\end{array}$ & $\begin{array}{l}\text { Portrait of } \\
\text { professional- } \\
\text { looking, business- } \\
\text { like men }\end{array}$ \\
\hline
\end{tabular}

\section{Proposed Method}

Based on the explanation above, this study proposes that the Malaysian Public HLIs' promotional materials must be analysed in accordance with the textual and visual metadiscourse models mentioned in the previous section. Against this backdrop, textual metadiscourse elements will be qualitatively analysed for their interactive and interactional resources. Similar to the textual element, the visual element will be analysed qualitatively according to the context to understand its rhetorical function in the promotional materials. Qualitative research is chosen to allow the researcher to conduct an in-depth study of a given situation rather than applying a single research approach (Bengtsson, 2016; Creswell, 2014).

In this study, the data collected from all the promotional materials are chosen to understand better the persuasive phenomenon brought by the materials under study. The Malaysian Public universities' promotional materials will be collected by downloading the official brochures and prospectus available on the Admission page on the official institutional website. All promotional materials' texts and visual fragments will be identified and classified according to Hyland's Interpersonal Framework of Metadiscourse (2005) and De Groot et al.'s Model of Visual Metadiscourse and Photographic Realization (2015). Drawing on these taxonomies, the visual element's linguistic analysis and contextual meaning will be analysed manually.

On another note, to ensure the trustworthiness of the analysis, an inter-rater agreement will be sought to ensure the credibility of the findings and avoid any potential shortcomings. Each rater will code the promotional materials independently and the level of agreement between the raters will be measured. A thick description of the research consisting of a firm account of data collection and specific details during the study phase and conducting an inquiry audit will be presented. These are to ensure the transferability and dependability elements which are the applicability and the accuracy of the findings, can be used in different settings and accurate (Guba \& Lincoln, 1983). As for the confirmability, reviewing the values that may impose on the research process will be observed. In sum, the entirety of the promotional materials of the Malaysian public universities will be analysed to acknowledge the persuasive appeals used in the promotional materials that are efficient in enticing the prospective students. 


\section{Conclusion}

Becoming a developed nation as ideally planned is much more than having a high number of university students. It is to ensure a progressive and persistent citizen can be moulded to face future challenges. In this regard, the learning process must be continuous to ensure a knowledgeable citizen. Hence, promotional materials by the Public HLIs should play their part in enticing the prospective students in pursuing their education regardless of their prior academic levels. Thus, by proposing suggestions on the emergent textual and visual metadiscursive elements in the current digital promotional materials, it is hoped that the Public HLIs promotional materials as a conduit can play a more effective role in influencing the prospective students to continue their studies at the respective institutions.

\section{References}

Adam, M. (2017). Persuasion in religious discourse: Enhancing credibility in sermon titles and openings . Discourse and Interaction, 5-25.

Amiryousefi, M. (2010). Metadiscourse: Definitions, issues and its implications for English teachers. English Language Teaching, 3 (4), 159-167.

Argyriou, E., \& Melewar, T. C. (2011). Consumer attitudes revisited: A review of attitude theory in marketing research. International Journal of Management Reviews, 13, 431451.

Bai, Y., Yao, Z., \& Dou, Y. F. (2015). Effect of social commerce factors on user purchase behavior: An empirical investigation from renren.com. International Journal of Information Management, 35 (5) , 538-550.

Baker, N. (2015). QS Quacquarelli Symonds. Retrieved from QS Quacquarelli Symonds web site: https://www.qs.com/what-cant-prospective-students-find-on-your-universitywebsite/

Bengtsson, M. (2016). How to plan and perform a qualitative study using content analysis. NursingPlus Open, 2, 8-14.

Bhatia, V. K. (2005). Generic patterns in promotional discourse. In H. Halmari, \& T. Virtanen, Persuasion across genres: A linguistic approach (130) (pp. 213-225). Philadelphia: John Benjamins.

Burrell, A. (2013). University World News. Retrieved from A University World News web site: https://www.universityworldnews.com/post.php?story $=20130328141317897$

Chaiken, S. (1980). Heuristic versus systematic information processing in the use of source versus message cues in persuasion. Journal of Personality and Social Psychology, 39, 752-766.

Creswell, J. W. (2014). Research design: Qualitative, quantitative, and mixed methods approaches. California: Sage Publications.

Cyr, D., Head, M., Lim, E., \& Stibe, A. (2015). The art of online persuasion through design: The role of issue involvement as it influences users based on prior knowledge. Fourteenth Annual Workshop on HCl Research in MIS (pp. 1-5). Texas: Association for Computing Machinery.

Cyr, D., Head, M., Lim, E., \& Stibe, A. (2018). Using the Elaboration Likelihood Model to examine online persuasion through website design. Information \& Management, 55 (7), 807-821.

De Groot, E., Nickerson, C., Korzilius, H., \& Gerritsen, M. (2015). Picture this: Developing a model for the analysis of visual metadiscourse. Journal of Business and Technical Communication, 1-37. 
Dillard, J. P. (2010). Persuasion. In C. R. Berger, M. E. Roloff, \& D. R. Roskos-Ewoldsen, The Handbook of Communication Science (pp. 203-218). California: Thousand Oaks.

Economic Planning Unit. (2021). Economic Planning Unit. Retrieved from Official Portal of Economic Planning Unit, Prime Minister's Department: https://www.epu.gov.my/en/sustainable-development-goals

Falk, C. F. (1984). De-marketing continuing education: the relationship of product and promotion. The Journal of Continuing Higher Education, 32 (2), 7-10.

Grapagasem, S., Krishnan, A., \& Mansor, A. N. (2014). Current trends in Malaysia Higher Education and the effect on education policy and practice: An overview. International Journal of Higher Education, 3 (1), 85-93.

Guadagno, R. E., \& Cialdini, R. B. (2009). Online persuasion and compliance: Social influence on the internet and beyond. In Y. Amichai-Hamburger, The social net: The social psychology of the internet (pp. 91-113). New York: Oxford University press.

Guan, E., Abdol Latif, L., \& Bahroom, R. (2011). Enculturation of Lifelong Learning: Perspectives from the New Economic Model. The International Lifelong Learning Conference 2011 (pp. 400-409). Kuala Lumpur: Open University Malaysia.

Guba, E. G., \& Lincoln, Y. S. (1983). Epistemological and methodological bases of naturalistic inquiry. Educational Communication and Technology, 30(4), 233-252.

Han, Z. (2014). The marketization of public discourse: The Chinese universities. Discourse \& Communication, 8 (1), 85-103.

Haugtvedt, C. P., \& Petty, R. E. (1989). Need for cognition and attitude persistence. Advances in Consumer Research, 16, 33-36.

Huang, Z., \& Benyoucef, M. (2015). User preferences of social features on social commerce websites: An empirical study. technological Forecasting and Social Change. 95, 57-72.

Hyland, K. (2004). Disciplinary interactions: Metadiscourse in L2 postgraduate writing. Journal of Second Language Writing, 13, 133-151.

Hyland, K. (2005). Metadiscourse. London: Continuum.

Hyland, K., \& Tse, P. (2004). Metadiscourse in academic writing: A reappraisal. Applied Linguistics 25(2), 156-177.

Ithnin, F., Sahib, S., Eng, C. K., Sidek, S., \& Harun, R. N. (2018). Mapping the futures of Malaysian Higher Education; A meta-analysis of futures studies in the Malaysian Higher Education scenario. Journal of Future Studies, 22 (3), 1-18.

Koomo, I. (2018). Transformasi Universiti Awam. Retrieved from https://ibrahimkoomoo.com:

https://ibrahimkoomoo.com/2018/02/25/transformasi-universiti-awam/

Kress, G., \& Van Leeuwen, T. (2006). Reading images: The grammar of visual design. London: Routledge.

Lampley, J. H., \& Owens, M. E. (2015). Website study: What information are prospective graduate students seeking? Journal of Academic Administration in Higher Education, 11 (2), 55-59.

Mathews, J. J., \& Arway, C. (1987). Marketing and logistical strategies for continuing education programs. Mobius: A Journal for Continuing Education Professionals in Health Sciences, 7 (2), 32-39.

Miniard, P. W., Bhatla, S., Lord, K. R., Dickson, P. R., \& Unnava, H. R. (1991). Picture-based persuasion processes and the moderating role of involvement. Journal of Consumer Research, 18, 92-107. 
Morrish, L., \& Sauntson, H. (2013). "Business-facing motors for economic development": An appraisal analysis of visions and values in the marketized UK university. Critical Discourse Studies, 10 (1), 61-80.

O'Keefe, D. J. (2002). Persuasion: Theory and research, 2nd ed. . London: Thousand Oaks.

Peracchio, L. A., \& Meyers-Levy, J. (2005). Using stylistic properties of ad pictures to communicate with customers. journal of Consumer Research, 32, 29-40.

Petty, R. E., \& Cacioppo, J. T. (1981). Issue involvement as a moderator of the effects of advertising content and context. Advances in Consumer Research, 11, 20-24.

Petty, R. E., \& Cacioppo, J. T. (1986). The Elaboration Likelihood Model of Persuasion. New York: Academic Press.

Petty, R. E., Kasmer, J. A., Haugtvedt, C. P., \& Cacioppo, J. T. (1987). Source and message factors in persuasion: A reply to Stiff's critique of the Elaboration Likelihood Model. Communication Monographs, 54 (3), 233-249.

Petty, R. E., Wheeler, S. C., \& Tormala, Z. L. (2003). Persuasion and attitude change. In T. Millon, \& M. J. Lerner, Handbook of Psychology; Personality and Social Psychology (pp. 353-382). New York: John Wiley \& Sons Inc. .

Popova, K. V. (2018). Persusaion strategy in online social advertising. Training, Language and Culture, 2 (2), 55-65.

Rucker, D. D., \& Petty, R. E. (2006). Increasing the effectiveness of communications to consumers: Recommendations based on Elaboration Likelihood and Attitude Certainty Perspectives. Journal of Public Policy and Marketing, 25 (1), 39-52.

Rucker, D. D., \& Petty, R. E. (2006). Increasing the effectiveness of communications to consumers: Recommendations based on Elaboration Likelihood and Attitude Certainty Perspectives. Journal of Public Policy and Marketing, 25 (1), 39-52.

Samad, Y., Salim, M. A., \& Akib, H. (2018). The functions of language in realizing the Indonesian culinary on the official tourism website of Indonesia: A tourism discourse perspective. IOSR Journal of Humanities and Social Science, 23 (10), 7-15.

Sarangi, S., \& Roberts, C. (1999). Talk, work and institutional order: Discourse in medical, mediation and management settings. Berlin: Mouton de Gruyter.

Schwarz, N., \& Bohner, G. (2001). The construction of attitudes. In A. Tesser, \& N. Schwarz, Handbook of Social Psychology: Intraindividual Processes (pp. 436-457). Hillsdale, NJ: Lawrence Erlbaum Associates.

Seo, K. (2020). Meta-analysis on visual presentation - Does adding images to texts influence persuasion? Athens Journal of Mass Media and Communications, 6 (3), 177-190.

Stiff, J. B. (1993). Persuasive Communication. New York: Guilford.

The World Bank. (2021). The World Bank. Retrieved from The World Bank Website: https://www.worldbank.org/en/news/pressrelease/2021/03/16/aiminghighmalaysia

Tormala, Z. L., \& Petty, R. E. (2004). Resistance to persuasion and attitude certainty: The moderating role of elaboration. Personality and Social Psychology Bulletin, 30, 14461457.

Kopple, V. W. (2002). Metadiscourse, discourse and issues in composition and rhetoric. In E. Barton, \& G. Stygall, Discourse Studies in Composition (pp. 91-114). New Jersey: Hampton Press.

Virtanen, T., \& Halmari, H. (2005). Persuasion across genres: Emerging perspectives. In H. Halmari, \& T. Virtanen, Persuasion across genres: A linguistic Approach (pp. 3-25). Philadelphia: John Benjamins Publishing Company. 
Wagner, B. C., \& Petty, R. E. (2011). The Elaboration Likelihood Model of Persuasion: Thoughtful adn non-thoughful social influence. In C. D, Theories in Social Psychology (pp. 96-116). Oxford: Wiley-Blackwell.

Wagner, B. C., \& Petty, R. E. (2011). The Elaboration Likelihood Model of Persuasion: Thoughtful and non-thoughtful social influence. In D. Chadee, Theories in Social Psychology (pp. 96-116). Oxford: Wiley-Blackwell.

World Bank. (2021). Aiming High- Navigating the Next Stage of Malaysia's Development. Washington DC: The World Bank. 